The original publication is available at:

Krishnan S, Greene SL, Khoury CK, Kuehny J, Miller AJ, Moreau T, Novy A (2020) People pollinating partnerships: harnessing collaborations between botanic gardens and agricultural research organizations on crop diversity. Acta Horticulturae 1298: 37-42. doi: 10.17660/ActaHortic.2020.1298.7.

https://doi.org/10.17660/ActaHortic.2020.1298.7

\title{
People pollinating partnerships: Harnessing collaborations between botanic gardens and agricultural research organizations on crop diversity
}

S. Krishnan ${ }^{1, a}$, S.L. Greene ${ }^{2}$, C.K. Khoury ${ }^{2,3}$, J. Kuehny ${ }^{4}$, A.J. Miller ${ }^{5,6}$, T. Moreau ${ }^{7}$ and A. Novy ${ }^{8}$ ${ }^{1}$ Denver Botanic Gardens, Denver, USA; ${ }^{2}$ United States Department of Agriculture, Agricultural Research Service (USDAARS), Fort Collins, USA; ${ }^{3}$ International Center for Tropical Agriculture (CIAT), Cali, Colombia; ${ }^{4}$ Louisinana State University

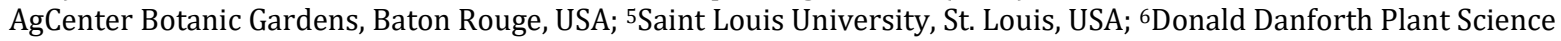
Center, St. Louis, USA; ${ }^{7}$ University of British Columbia Botanical Garden, Vancouver, Canada; ${ }^{8}$ San Diego Botanic Garden, Encinitas, USA.

aE-mail: krishnas@botanicgardens.org

Abstract

The world's botanic gardens are repositories of plant diversity but are seldom considered to be major contributors to conservation and research of crops. Thus, botanic gardens and agricultural research organizations have had somewhat limited interactions historically. An unprecedented three-year collaboration between the American Society of Agronomy, Crop Science Society of America, Soil Science Society of America, the American Public Gardens Association, and the World Food Prize Foundation brought together experts from botanic gardens and the agricultural research community, culminating in a Symposium in April 2019 in Des Moines, Iowa. Funded by a grant from the United States Department of Agriculture - National Institute of Food and Agriculture (USDA - NIFA), one of the major outcomes of this collaboration was the development of a shared Road Map for conservation, use, and public engagement around North America's crop wild relatives and wild utilized plants - species of interest to both communities. Key takeaways from this collaboration are discussed.

Keywords: Botanic Gardens, Collaborations, Conservation, Crop Diversity, Crop Wild Relatives

\section{INTRODUCTION}

Since food plant domestication commenced over 10,000 years ago, the fate of both people and cultivated plants have become inextricably linked, (Knapp, 2019; Schaal, 2019). Integral to the persistence and adaptation of human societies has been the accumulation of cultural knowledge on food production - from when and how to plant, to how to protect crops from pests and diseases, to when and how to harvest and process plants for consumption (Krishnan et al., 2019). Integral also is knowledge on the wild relatives of our crop species, since these plants offer valuable traits for crop breeding, including adaptation 
to climate change and resistance to pests and diseases (Dempewolf et al., 2017; Hajjar and Hodgkin, 2007).

The recently published UN report by the Intergovernmental Science-Policy Platform on Biodiversity and Ecosystem Services (IPBES) estimates that over one million plant and animal species are at risk of extinction. Included among them are local varieties and breeds of domesticated plants and animals, and their progenitors and wild relatives, whose loss would undermine the resilience of many agricultural systems to threats such as pests, pathogens and climate change, posing significant risk to global food security (IPBES, 2019). The UN Sustainable Development Goals has also recognized the importance of conserving crop diversity. Target 2.5 under Goal 2 of "end hunger, achieve food security and improved nutrition and promote sustainable agriculture" states that "by 2020, maintain the genetic diversity of seeds, cultivated plants and farmed and domesticated animals and their related wild species, including through soundly managed and diversified seed and plant banks at the national, regional and international levels, and promote access to and fair and equitable sharing of benefits arising from the utilization of genetic resources and associated traditional knowledge, as internationally agreed" (UN Sustainable Development Goals Knowledge Platform, 2019). Unfortunately, we are already at the eve of 2020 and even though progress is being made to conserve crop and livestock diversity, this target will not be fully achieved by the target date.

In order to achieve shared goals on agricultural biodiversity, multi-disciplinary partnerships and collaborations among institutions with differing missions such as those involved in plant conservation, land management, agricultural science, and botanical education and outreach becomes necessary. Botanic gardens around the world are repositories of plant diversity but are seldom considered to be major contributors to conservation and research of crops. With over 120,000 plant species maintained as living collections or in seed banks distributed over 3,000 global botanic gardens, they have the potential to play a tremendous role in complementing germplasm repositories held by major agricultural research centers such as CGIAR, the United States Department of Agriculture, National Plant Germplasm System, and other national genebanks. In addition, annually botanic gardens attract 250 million visitors providing a unique opportunity to engage the public in informal education about and direct experience with plants (Miller et al. 2015). Many botanic gardens are also involved in in situ conservation and ecological restoration, making them prime candidates for monitoring and conserving crop wild relatives in their natural habitats (Krishnan and Novy, 2016). Unfortunately, historically, botanic gardens and agricultural research organizations have had somewhat limited interactions. To overcome barriers and engage these two communities, an unprecedented collaboration was developed between the botanic garden and agricultural research communities.

\section{MATERIALS AND METHODS}

In 2016, a joint collaboration between the Alliance of Crop, Soil, and Environmental Science Societies (ACSESS) and the American Public Gardens Association (APGA) was funded by the United States Department of Agriculture - National Institute of Food and Agriculture (USDA - NIFA), the U.S. Botanic Garden and Liechtag Foundation with the aim of engendering greater collaborations between botanic gardens and agricultural researchers to advance crop diversity conservation and research in North America. The specific objectives of this project were: 
1. Create a strong collaboration between botanic gardens and researchers in the field of agronomy by creating a core group representing both communities;

2. Engage the core group in dialogues to identify and create the content for a symposium to be held in 2019; and

3. Implement the symposium on crop diversity and agricultural education at botanic gardens.

The ultimate goal was to create an enduring relationship between these two sectors that historically have not collaborated before.

The first core group meeting was held in conjunction with the ACSESS annual conference in Orlando, Florida in October 2017. At this meeting several sub-committees were formed and each sub-committee was tasked with a specific topic to tackle for content delivery at the Crop Diversity Symposium. The second meeting of the core group was held in conjunction with the APGA conference in Anaheim, CA in June 2018. More symposium logistics were worked out at this time. At both meetings, participants also had the opportunity to share their work with the larger conference community. Following substantial further interaction between the organizing researchers, the symposiumCelebrating Crop Diversity: Connecting Agriculture, Public Gardens, and Science -was held April 2-4, 2019 in Des Moines, Iowa at the World Food Prize Foundation.

\section{RESULTS AND DISCUSSION}

The Celebrating Crop Diversity: Connecting Agriculture, Public Gardens, and Science symposium was attended by over 200 participants spanning both botanic garden and agricultural research communities, as well as related fields including land managers and plant science academics. Key topics that were discussed at the symposium were:

- Conservation and use of crop wild relatives

- Public gardens and museums engaging in science communication

- Building partnerships through collaborations with scientists and extension agents

- Crop breeding projects

As part of the collaboration and in preparation for the Symposium, a road map for conservation, use, and public engagement around North America's crop wild relatives and wild utilized plants was developed by the organizing researchers. The road map was refined and improved with input from a wide range of agricultural and botanical researchers, land managers, scientists, plant breeders, and educators, both through online surveys and during in-person stakeholder consultations at the Symposium.

The road map for the conservation, use, and public engagement around North America's crop wild relatives and wild utilized plants lays out five high priority action items as outlined below (Khoury et al., 2019a, 2019b, and 2019c):

\section{Understand and document North America's crop wild relatives and wild utilized plants, assess threats to their natural habitats, and determine gaps in their conservation.}

Species inventories and conservation assessments have been generated for various taxa and for some geographic regions in North America, but many land management areas have no comprehensive species lists, and for many species, assessments are either out of date or have not yet been performed. Assessments are needed to further document and define the highest priority species across North America, understand spatial patterns 
with regard to their genetic diversity, analyze threats to populations, and identify the most important gaps in conservation. Results should be integrated into relevant information platforms used by the conservation, land management, genetic resource, and agricultural research communities, and these platforms should more easily align. The information and priorities must be shared widely with professionals in the conservation, land management, agricultural science, and outreach communities, as well as with the public.

\section{Protect North America's crop wild relatives and wild utilized plants in their natural habitats.}

North America's public, private, military, Indigenous and First Peoples', and other open spaces conserve numerous crop wild relative and wild utilized plant populations collaterally, because of overall land protection practices. These plants are not explicitly prioritized except in a few exceptional cases, e.g., for some chile pepper, cranberry, and maize wild relative populations. Most species are not currently sufficiently conserved in their natural habitats. Conservation sites covering populations of the highest priority and/or most threatened crop wild relatives and wild utilized plants need to be designated in existing protected areas, and additional protected areas might need to be considered, to adequately protect the genetic diversity of these plants in their natural habitats so they can continue to evolve. To do so, priorities for species conservation will need to be expanded beyond those few currently officially listed as threatened and endangered.

3. Collect and conserve North America's prioritized crop wild relatives and wild utilized plants in ex situ collections.

Ex situ collections of important crop wild relatives and wild utilized plants are maintained in botanic gardens and public genebanks across North America, but these collections are not complete with regard to coverage of taxa, nor of genetic diversity within species. Prioritized crop wild relatives and wild utilized plants across North America need further collecting for ex situ conservation. This will require coordination by botanic, taxonomic, and conservation experts, capitalizing on local botanical expertise, while hopefully also providing much needed training and educational opportunities for additional participants. Further research is needed to develop techniques for the maintenance of species that currently require expensive, non-standard approaches.

4. Make North America's crop wild relatives and wild utilized plants accessible and attractive to plant breeders, researchers, and educators.

North America's botanical gardens, public genebanks, and open spaces provide the foundation for making crop wild relatives and wild utilized plants accessible for research and education. These plants need to be carefully managed to ensure adequate, high quality, true to type propagules are available for distribution, and they need to be easily accessible via online databases. Indigenous, traditional, and local knowledge about these plants must be valued and protected through access provided by agreements based on mutually agreed terms. These plants should also be accessible to the public through botanic garden displays and through information initiatives on public lands. 


\section{Raise public awareness about North America's crop wild relatives and wild utilized plants.}

Creating coordinated educational and communications programs to help raise awareness and provide a backdrop for support of crop wild relative and wild utilized plant conservation is necessary to the long-term viability of conservation and plant breeding efforts. Skilled education and outreach professionals should lead collaborative efforts to raise awareness about the importance of, and threats to, North American crop wild relatives and wild utilized plants.

These five priorities are interdependent and require collaborative, coordinated efforts. Through partnerships, significant further progress can be made in conservation, use, and public engagement around North American crop wild relatives and wild utilized plants.

\section{LOOKING FORWARD}

Agricultural biodiversity is one of the foundations of the food systems that nourish us. While the outcomes of the Celebrating Crop Diversity symposium will take root and grow in years to come, two key achievements ensure the next steps are underway. First, the publication of the roadmap in the journal Crop Science (Khoury et al., 2019a) and parallel publications for the land manager (Khoury et al., 2019b), botanic gardens (Khoury et al., 2019c), and this International Society for Horticultural Science community will offer permanent homes in the scientific and practitioner literature for our shared aspirations with regard to crop wild relatives. Second, organizers are circulating and asking for input into the road map to engage as many interested stakeholders as possible and to ensure that the priorities reflect those of the wider community. Anyone interested in joining this effort are encouraged to contact the main author.

The collaborative process of planning and hosting Celebrating Crop Diversity successfully brought together individuals and their networks for the shared goals of agricultural research and public engagement on plants. We hope that the outcomes of the relationships built and the interdisciplinary dialogues begun at the Symposium will continue and expand in the years to come.

\section{ACKNOWLEDGMENTS}

We thank the Alliance of Crop, Soil, and Environmental Science Societies (ACSESS) and the American Public Gardens Association (APGA) for their facilitation of a collaborative platform to discuss synergies across North American agricultural and botanical organizations, supported by USDA NIFA (grant 2017-67019-26289), the US Botanic Garden, the Leichtag Foundation, and the World Food Prize Foundation. The USDA is an equal opportunity employer and provider.

\section{Literature Cited}

Dempewolf, H., Baute, G., Anderson, J., Kilian, B., Smith, C., and Guarino, L. (2017). Past and future use of wild relatives in crop breeding. Crop Science 57(3):1070.

Hajjar, R., and Hodgkin, T. (2007). The use of wild relatives in crop improvement: a survey of developments over the last 20 years. Euphytica 156:1-13. 
IPBES. (2019). Summary for policymakers of the global assessment report on biodiversity and ecosystem services of the Intergovernmental Science-Policy Platform on Biodiversity and Ecosystem Services. S. Díaz, J. Settele, E. S. Brondizio E.S., H. T. Ngo, M. Guèze, J. Agard, A. Arneth, P. Balvanera, K. A. Brauman, S. H. M. Butchart, K. M. A. Chan, L. A. Garibaldi, K. Ichii, J. Liu, S. M. Subramanian, G. F. Midgley, P. Miloslavich, Z. Molnár, D. Obura, A. Pfaff, S. Polasky, A. Purvis, J. Razzaque, B. Reyers, R. Roy Chowdhury, Y. J. Shin, I. J. Visseren-Hamakers, K. J. Willis, and C. N. Zayas (eds.). IPBES secretariat, Bonn, Germany. 39 pages.

Khoury, C.K., Greene, S.L, Krishnan, S., Miller, A.J., and Moreau, T. (2019a). A Road Map for Conservation, Use, and Public Engagement around North America's Crop Wild Relatives and Wild Utilized Plants. Crop Science. 59, 1-6 DOI: 10.2135/cropsci2019.05.0309.

Khoury CK, Greene SL, Moreau T, Krishnan S, Miller AJ, Williams KL, Rodriguez-Bonilla L, Spurrier C, Zalapa J, and Nabhan GP (2019b) Toward integrated conservation of North America's Crop Wild Relatives. Natural Areas.

Khoury CK, Greene SL, Moreau T, Krishnan S, and Miller AJ (2019c) Botanic Garden - Agriculture Research Collaborations around North America's Crop Wild Relatives and Wild Utilized Plants. Public Garden.

Knapp, S., (2019). People and Plants: The Unbreakable Bond. Plants, People, Planet, 1(1), 20-26 https://doi.org/10.1002/ppp3.4

Krishnan, S., Moreau, T., Kuehny, J., Novy, A., Greene, S.L. and Khoury, C.K. (2019). Resetting the table for people and plants: Botanic gardens and research organizations collaborate to address food and agricultural plant blindness. Plants, People, Planet, 1(3), 157-163 https://doi.org/10.1002/ppp3.34.

Krishnan, S. and Novy, A. (2016). The role of botanic gardens in the twenty-first century. CAB Reviews. 11(23):1-10. DOI: 10.1079/PAVSNNR201611023.

Miller, A.J., Novy, A., Glover, J., Kellogg, E.A., Maul, J.E., Raven, P., and Wyse Jackson, P. (2015). Expanding the Role of Botanical Gardens in the Future of Food. Nature Plants 1(6): 15078. https://doi.org/10.1038/nplants.2015.78.

Schaal, B. (2019). Plants and People: Our Shared History and Future. Plants, People, Planet, 1(1): 14-19 https://doi.org/10.1002/ppp3.12

UN Sustainable Development Goals Knowledge Platform. (2019).

https://sustainabledevelopment.un.org/sdg2. Accessed October 27, 2019. 